\title{
Grande Sertão: VeredAs COMO GeSto \\ TESTEMUNHAL E CONFESSIONAL
}

Márcio Seligmann-Silva

* (FOUCAULT, M. História da sexualidade. 1 A vontade de saber. trad. M. T. da Costa Albuquerque e J.A. Guilhon Albuquerque, Rio de Janeiro: Graal, $15^{\mathrm{a}}$ ed., 1988: 58.)

* (lbidem: 59.)

* (lbidem: 59.)

\section{Confissão e testemunho como dispositivos}

Michel Foucault nos anos 1970 insistiu muito no papel da confissão como uma técnica específica, poderíamos dizer, como um dispositivo de construção da verdade e do indivíduo. "Desde a Idade Média, pelo menos" - ele escreveu no primeiro volume de sua História da Sexualidade - "as sociedades ocidentais colocaram a confissão entre os rituais mais importantes de que se espera a produção da verdade." Com efeito, nossa sociedade está marcada pela confissão e isto, nota ainda Foucault, não apenas no âmbito religioso e jurídico, mas também "na medicina, na pedagogia, nas relações amorosas, na esfera mais cotidiana e nos ritos mais solenes; confessam-se os crimes, os pecados, os pensamentos e os desejos, confessam-se passado e sonhos, confessa-se a infância; confessam-se as próprias doenças e misérias; emprega-se a maior exatidão para dizer o mais difícil de ser dito; confessa-se em público, em particular, aos pais, aos educadores, aos médicos àqueles que se ama; fazem-se a si próprios, no prazer e na dor, confissóes impossíveis de confiar a outrem, com o que se produzem livros". A confissão se tornou tão essencial dentro de nosso regime de construção da verdade que, quando ela não é espontânea, é arrancada pela tortura. Em um tom que não deixa de ser muito nietzschiano, Foucault sentenciou: "O homem, no Ocidente tornou-se um animal confidente." ${ }^{*} \mathrm{O}$ importante, no nosso contexto, é destacar que para este autor esta virada confessional do homem ocidental teve profundas consequências na literatura. Para ele, a partir de então passamos da tradição da narrativa que apresentava provas de bravura ou de santidade, para uma literatura que tem como fim a apresentação de verdades escondidas dentro dos indivíduos. A confissão tem um efeito de verdade.

A confissão foi introduzida pelo Concílio de Latrão em 1215. Ela está de certo modo na origem dos tribunais de Inquisição e, por outro lado, seu desenvolvimento como dispositivo de construção da verdade foi paralelo ao recuo de provações de culpa, como 
o duelo. De certo modo este modelo de verdade - Foucault bem o sabia - não foi uma criação medieval, pois já pode ser encontrado nos primórdios do Ocidente. Mas foi a partir de então que a confissão tomou o lugar que de certa maneira mantém até hoje. No limite, Foucault faz da confissão cristã uma espécie de Urphänomen, protofenômeno, da psicanálise.

Mas existe também outro dispositivo, próximo ao de confissão mas distinto, o de testemunho, que Foucault não explora ou subsume àquele. Para entendermos a complexidade das manifestações simbólicas que se estruturam a partir da elocução do eu e nos aproximarmos do modelo de verdade calcado no segredo dos indivíduos, o conceito de testemunho é no mínimo tão importante quanto o de confissão. Na cena do tribunal - que de certa forma é o local paradigmático da confissão - ouvimos também os testemunhos daqueles que viram o ato que está sob a lupa do julgamento. Em resumo, o réu confessa, as testemunhas testemunham, assim como, no registro religioso, testemunhamos nossa fé e confessamos nossos pecados. Existe também uma relação de complementaridade entre um gesto e outro, como lemos na definição de confissão do Houaiss: "revelação, diante de testemunha(s) privada(s) ou pública(s), que alguém faz de um ato censurável que cometeu." Mas o testemunho deve ser entendido tanto como a apresentação do ponto de vista de um terceiro - terstis -, de onde se deriva a noção latina de testis, testemunho jurídico que se quer objetivo, como também deve ser abordado como a tentativa de se apresentar uma experiência que resiste a esta apresentação. $\mathrm{O}$ testemunho neste segundo sentido sofre um deslocamento da elocução da verdade para a própria pessoa que testemunha. Passa-se do testemunho pretensamente objetivo, para a subjetividade da testemunha. Ela é, como notou Benveniste, superstes, testemunha sobrevivente. ${ }^{*}$ Ela tenta apresentar o real, a saber, o que escapa ao simbólico, mas esta apresentação é sempre também apresentação da impossibilidade de se apresentar. O testemunho está submetido ao double bind de sua simultânea necessidade e impossibilidade. É verdade que, apesar de testemunho e confissão serem distintos, podemos dizer que no ato de confissão encontramos também testemunhos e não se pode descartar a possibilidade de em meio a um testemunho brotar uma confissão. E mais, ambos, como são lançados paradigmaticamente na cena do tribunal, têm a ver com culpa e culpabilização, ou com inocência. Deste modo, a ideia de justiça é a força motriz que está por detrás
* (BENVENISTE, E. O Vocabulário das Instituições Indo-européias. Volume II: POder, Direito, religião, trad. D. Bottmann, Campinas: UNICAMP, 1995: 277; cf. SELIGMANN-SILVA, M. "Testemunho e a Política da Memória: O Tempo depois das Catástrofes", in: Projeto História, Revista do Programa de Estudos Pós-Graduados em História e do Departamento de História da PUC-SP, $n^{\text {o. }} 30$, pp. 31-78, jun. 2005.) 
* (Santo AGOSTINHO. Confissões. trad. J. O. Santos e A. A. de Pina, Petrópolis: Vozes, 1987: 221.) tanto da confissão, como do testemunho. Uma justiça que paira como uma possibilidade de redenção: dos males, das culpas, dos pecados, como uma purificação catártica, que leva o julgado a uma nova vida. Tanto o testemunho como a confissão visam o veritatem facere - trata-se de uma troca de apresentação da nudez, do pacto e do preço da nudez: colocamo-nos nus diante Dele para que Ele mostre a verdade nua. A nudez volta-se a uma outra nudez. ${ }^{1} \mathrm{~Pa}$ ra Santo Agostinho a confissão implica o desnudar-se diante de Deus. A verdade aqui é também a da cena do tribunal: a autoapresentação visa um testemunho, apresentar a vida para voltar à vida (revixit). "Acusa-te, glorifica-o", escreve Santo Agostinho. Nesta cena o dentro volta-se para fora. Pois, como Derrida recorda a partir de Santo Agostinho, a confissão apresenta não apenas o que sabemos de nós, mas também aquilo que ignoramos. ${ }^{*} \mathrm{O}$ escondido, o esquecido, vem à tona: Unheimlich (o estranho, sinistro). A palavra da confissão é sempre palavra de "conversão": de circonfissão, dirá Derrida; é palavra-ação, ato de différance, momento de crise, transbordamento, metamorfose, diríamos depois de Kafka.

\section{Testemunha ocular e testemunho do invivível}

Neste espaço gostaria de apresentar a possibilidade de se ler o romance Grande Sertão: Veredas, a partir de seus traços testemunhais e confessionais. É claro que a confissão e o testemunho são mais do que evidentes neste romance, mas gostaria de desdobrar os aspectos aporéticos destes atos e sobretudo ver como podem ser lidos neste livro, por um lado o confessional como ato de linguagem e simbólico e, por outro, o testemunhal, enquanto testis e superstes. A ideia é não tratar confissão e testemunho como gêneros tradicionais, como tem sido feito na teoria literária, mas repensar estes conceitos, com ajuda da psicanálise e da filosofia. Trata-se também de ver este romance como uma performance da memória e do ato de recorda-

\footnotetext{
${ }^{1}$ Se na confissão existe um despimento metafórico que muitas vezes, simbolicamente, torna-se literal, na cena do testemunho frequentemente esta nudez é parte da estratégia de humilhação e de tortura na busca da "verdade". Espera-se extrair a verdade do indivíduo submetido à humilhação do desnudamento público. Este colocar a nu da testemunha visando à transparência da verdade é um desdobramento da visão judaico-cristã da vestimenta como encobrimento da culpa e do pecado. É como se a nudez fosse a condição da inocência, da fala direta dos indivíduos e de seus corpos antes da nossa autoconsciência e da capacidade de distinguir o bem e o mal. O torturador que humilha desnudando o torturado se coloca na posição de um pequeno deus que devolveria a inocência a um corpo que pecou. Mas trata-se, evidentemente, de um deus perverso.
} 
ção. Se atos literários testemunhais tiveram momento desde o século XVIII, foi no século XX que assistimos ao surgimento de uma literatura com forte teor testemunhal. Não diria que existe a partir de então um novo gênero, a literatura de testemunho, mas antes que neste século tanto se desenvolveu uma literatura com forte teor testemunhal, como também, por outro lado, aprendemos a ler nos documentos de cultura traços, marcas da barbárie. ${ }^{2} \mathrm{O}$ excesso de catástrofes impingidas pelas nossas próprias mãos - nesse século cerca de 140 milhões morreram por atos bárbaros em guerras, genocídios e perseguições - gerou uma necessidade de testemunho.

Guimarães Rosa conseguiu canalizar para seu romance de 1956 as fantásticas forças retóricas tanto da confissão, como do testemunho. ${ }^{3}$ Riobaldo narra suas memórias a um paciente senhor. O romance é o teatro de suas memórias e o fio que mantém toda a tensão da trama é o relacionamento amoroso e posto como condenável entre ele e Diadorim. O segredo é apenas revelado no final da narrativa-confissão-testemunho. $\mathrm{O}$ ponto de vista subjetivo, do narrador em primeira pessoa, que apresenta por um lado o que viu e, por outro, o que viveu, suas emoções e sofrimentos é apresentado de modo exemplar por Rosa na expressão de Riobaldo: "Coisas que vi, vi, vi - oi... "* Ver e viver fundem-se aqui. O romance contém tanto elementos confessionais, como também o testemunho

${ }^{2} \mathrm{O}$ conceito de "teor testemunhal" desenvolvi em outros textos (cf. SELIGMANNSILVA, História, Memória, Literatura: o Testemunho na Era das Catástrofes, op. cit.). Para tanto parti dos conceitos benjaminianos de "teor de verdade" (Wahrheitsgehalt) e de "teor coisal" (Sachgehalt), que ele desenvolveu em seu ensaio sobre As afinidades eletivas de Goethe e, por outro lado, da sua famosa frase segundo a qual "es ist niemals ein Dokument der Kultur, ohne zugleich ein solches der Babarei zu sein". ("Nunca existiu um documento da cultura que não fosse ao mesmo tempo um [documento] da barbárie." BENJAMIN, W. Gesammelte Schriften. Frankfurt a.M.: Suhrkamp, vol. I: Abhandlungen, 1974: 696). Considero mais produtivo se estudarem os traços característicos deste teor testemunhal, que pode ser encontrado em qualquer produção cultural, do que se falar em um gênero "literatura de testemunho". Esta expressão, por outro lado, tem sido aplicada àquelas obras programaticamente nascidas para testemunhar catástrofes no século XX. Não considero errado se falar em literatura de testemunho, mas creio que não devemos reduzir o estudo do teor testemunhal a esta produção específica.

${ }^{3}$ Neste texto analiso os aspectos da performance testemunhal e confessional do romance de Rosa, sem levar em conta a relação do teor testemunhal desta obra com a sua vida e a sua época. Pesquisas neste sentido têm sido feitas com frutos muito interessantes por Jaime Ginzburg (GINZBURG, Jaime. Guimarães Rosa e o terror total. In: CORNLSEN, Elcio Loureiro, (org.). Literatura e guerra. Belo Horizonte: FALE-UFMG, 2009 (no prelo). Outro autor muito propício para um estudo tanto desta performance como também da relação entre sua vida e o teor testemunhal é Graciliano Ramos.
* (ROSA, G. Grande Sertão: veredas. Rio de Janeiro: Livraria José Olympio Editora, 14 ed., 1980: 54.) 
em suas duas faces: a de testemunho ocular, testis, e a de testemunho como tentativa de apresentação do inapresentável, superstes. $\mathrm{O}$ senhor a quem ele se dirige é uma construção complexa e essencial na situação testemunhal e confessional. Trata-se de um "outro" a quem ele se dirige. Este outro vai tornar-se testemunha secundária das histórias. Daí a expressão recorrente na pontuação do texto, quando o narrador se volta para este senhor e afirma: "Mire veja". Nós todos estamos mirando e vendo, traduzindo o teatro de palavras em imagens. Toda confissão deve voltar-se para uma outra pessoa. Também no caso do testemunho este outro-ouvinte é absolutamente fundamental. A catarse testemunhal é passagem para o outro de um mal que o que testemunha carrega dentro de si. Para se fazer o trabalho do trauma exige-se uma espécie de trabalho de luto da experiência sofrida: um enterro ritual do passado que muitas vezes inclui mortos, como é o caso da narrativa de Riobaldo, com sua longa vida de jagunço sendo desfiada diante do "senhor" e que também porta o luto pela morte de Diadorim.

\section{Um espaço mnemônico intenso}

Mas este senhor a quem ele se dirige é também, como é evi-

* (Ibidem: 108.)

* (lbidem: 173.)

* (Ibidem: 67.)

* (Ibidem: 52.) dente, o leitor. "Mas o senhor calado convenha", escreve Rosa não sem certa malícia." O leitor é fim, o telos, da escrita, aquele a quem a "mensagem imperial" está direcionada. Este senhor é descrito como muito instruído, como alguém do sexo masculino* e paciente. A matéria do livro, a memória de Riobaldo, é apresentada a este ouvinte paciente de modo não linear. Trata-se da apresentação e simultânea construção de um espaço mnemônico intenso, sem começo ou fim, com uma temporalidade apenas parcialmente cronológica e muito mais emocional. "No real da vida, as coisas acabam com menos formato, nem acabam”, formula Riobaldo. ${ }^{*}$ E ainda, o professor Tatarana também diz (com Lacan): "Digo: o real não está na saída nem na chegada: ele se dispõe para a gente é no meio da travessia." Os cronotopoi se entrecruzam, em curtos-circuitos espaçotemporais, como também costuma acontecer em narrativas de testemunho. Riobaldo constrói sua topografia emocional da memória, passando por cronotopoi que lhe marcaram a vida. Mas em Rosa, evidentemente, trata-se de uma construção literária e isto se dá de modo assumidamente artístico e autoreferente. As inúmeras intervençōes meta-narrativas, nas quais Riobaldo se volta para seu interlocutor, na verdade um ouvinte-leitor, estão cheias desta astúcia de 
um autor que ao mesmo tempo que constrói sua narrativa-fluxo-dememória, campo espaço-temporal, também como que puxa o leitor para fora deste rizoma. Assim ele pode convencê-lo melhor de sua existência e potência. A nós só resta admirar a galáxia-mnemônica de Riobaldo em suas sístoles e diástoles - e nos emocionar.

Riobaldo é o primeiro a afirmar que sua narrativa é fragmentada. Ela é saturada de emoções. Trata-se da mise en scène de uma memória traumática, marcada pela "literalidade", ou seja, por sua tendência ao fragmento, a ser caco do passado. A construção narrativa é o meio de articular estes fragmentos. Seu fio narrativo executa saltos, assim como o universo de nossa memória o faz, comandada tanto pelo princípio das afinidades eletivas, como por exigências emocionais. Uma porta em um hic et nunc permite que se escorregue para outro lugar-tempo, como no túnel em que cai Alice e a leva ao país das maravilhas, ou nas portas de Matrix. A contiguidade é uma função qualitativa e não quantitativa. Assim lemos em uma das referidas passagens meta-narrativas uma clara teoria do que se passa no próprio livro:

A lembrança da gente se guarda em trechos diversos, cada um com seu signo e sentimento, uns com os outros acho que nem não misturam. Contar seguido, alinhavado, só mesmo sendo as coisas de rasa importância. De cada vivimento que eu real tive, de alegria forte ou pesar, cada vez daquela hoje vejo que eu era como se fosse diferente pessoa. Sucedido desgovernado. [... ] O senhor é bondoso de me ouvir. Tem horas antigas que ficaram muito mais perto da gente do que outras, de recente data. O senhor mesmo sabe. [...] O que muito lhe agradeço é a sua fineza de atenção.*

* (lbidem: 77 ss.)

Este tempo qualitativo e submetido a esta lei emocional da proximidade é apresentado em doses diversas de detalhe. Às vezes Riobaldo apenas indica que aconteceu uma batalha, sem entrar em seus meandros. Noutras apresenta longamente diálogos e trocas de olhares com Diadorim.

A construção deste campo mnemônico é o presente, o agora da narrativa que ao se desdobrar traça este mesmo campo. Esta presentificação do passado, típica dos atos de confissão e de testemunho, é explicitada na frase: "Comigo, as coisas não têm hoje e ant'ontem amanhã: é sempre." Note-se que ao tratar desta tem* (lbidem: 109.) poralidade na chave do "sempre" a narração é aproximada também da memória traumática: que se inscreve como um passado que não passa. Riobaldo diz que "lembro de tudo" e que fala demais de seu passado porque está velho. ${ }^{*}$ De fato, os traumatizados como que

* (Ibidem: 112.) 
* (Ibidem: 27.)

* (Ibidem: 41.)

* (Ibidem: 331.)

* (Ibidem: 166.) sofrem de excesso de memória: uma ótima definição para Riobaldo. Mas esta lembrança, que é apresentada como sendo a matéria do livro, é também um folhear a vida de trás pra frente, como os idosos costumam fazer. Daí a formulação surpreendente: "Eu me lembro das coisas, antes delas acontecerem...” As coisas só se tornam "coisas" no próprio ato de recordação. É este ato que as funda como fatos. As lembranças assumem a tintura da nostalgia e da saudade, com sua ambígua tonalidade de alegria e melancolia. Mas seus nós são constituídos justamente por aquilo que é encenado como irrepresentável: seu amor por Diadorim, as mortes e violências, como o sofrimento da passagem do Liso do Sussuarão: este espaço atópico, espécie de dobra na banda de Moebius, deserto de onde acena o buraco negro do real. Descrevendo este martírio para o "senhor", o narrador diz: "o que não pode, para o senhor, é ter sido, vivido.”* Já em outra ocasião Riobaldo nota que o que apresenta é pouco crível: o que dispara uma angústia na testemunha que quer contar com a benevolência do seu interlocutor: "O senhor mire e veja, o senhor: a verdade instantânea dum fato, a gente vai departir, e ninguém crê. Acham que é um falso narrar." Este elemento inverossímil da passagem pela morte também é tópico nas narrativas de catástrofes do século XX. O inverossímil desconstrói a narrativa e seu decoro. Para a poética clássica, como é conhecido, o impossível que persuade é preferível ao que pode acontecer, mas não é persuasivo. $\mathrm{O}$ ter vivido o excepcional antes de abalar os modos de apresentação produz uma quebra no próprio eu, daí a afirmação que vimos de Riobaldo: "vejo que eu era como se fosse diferente pessoa." Noutra passagem ele formula: "Fui eu? Fui e não fui." ${ }^{\prime *}$ Nos testemunhos de catástrofes é frequente os sobreviventes se verem como um outro. $\mathrm{O}$ eu se desloca para um ele ou ela. A construção do testemunho tem justamente a função de aproximar os cacos deste outro-eu-narrado.

Mas o senhor-interlocutor é também alguém que está invadindo o segredo íntimo da testemunha e do confessor. Esta invasão, no entanto, é desejada, pois permite não só o ato testemunhal e a confissão, mas também, como o senhor é de fora e se vai após ouvir/ler a história, cria espaço também para um paradoxal solilóquio a dois. Ou seja, o dispositivo de enunciação do eu é a oportunidade de construção de uma narrativa: de uma vereda por onde o mal pode fluir. O leitor - como a temporalidade - é o leito por onde o rio pode correr. $\mathrm{O}$ testemunho e a confissão visam uma paradoxal apresentação que é ao mesmo tempo memória e esqueci- 
mento. Só no branco do esquecimento que a imagem da memória pode ser deitada. Além disto, a memória do trauma deve ser ao mesmo tempo apresentada e afastada. Embalada na nau da narração. Mas para isto acontecer necessita-se de um "tu". O senhor é caracterizado como "estranho" e é a este estranho que Riobaldo revela seu estranho - Unheimlich - eu.

Não devia de estar relembrando isto [ou seja, a paixão por Diadorim], contando assim o sombrio das coisas. Lenga-lenga! Não devia de. $\mathrm{O}$ senhor é de fora, meu amigo mas meu estranho. Mas talvez por isto mesmo. Falar com o estranho assim, que bem ouve e logo longe se vai embora, é um segundo proveito: faz do jeito que eu falasse mais mesmo comigo. Mire veja: o que é ruim, dentro da gente, a gente perverte sempre por arredar mais de si. Para isto é que o muito se fala?*

* (Ibidem: 33.)

\section{Riobaldo como catador de logoi. Epopeia no sertão}

Este "muito falar" nasce de uma necessidade, exatamente como o testemunho. Riobaldo mesmo pondera: "o tudo que eu conto, é porque acho que é sério preciso." ${ }^{*}$ Mas este Riobaldo não é um jagunço típico, afinal ele não só domina muito bem o idioma, como até mesmo se gaba de sua suprema memória. Não nos esqueçamos que ele é também professor, como na alcunha com a qual Zé Bebelo o trata. Este loquaz ex-jagunço narra para um estranho, doutor, homem de letras. E nós - homens de letras - lemos isto tudo da pena de um autor implícito, também ele doutor e homem de letras, mas um estranho ao mundo de Riobaldo. Percebemos, portanto, que a figura do "senhor" receptor da narrativa pode ser interpretada tanto como o leitor como o próprio autor implícito. Este último, por sua vez, constrói-se como um coletor de logoi do sertão. Ele coleciona histórias, a vox populi. Ele é uma espécie de Lumpensammler. Ao invés da figura (aristocrática) do escritor que trabalha no gabinete, ele executa seu trabalho de escrita a partir de um arquivo resultado de seu trabalho como "catador". Benjamin, no seu "Paris do Segundo Império em Baudelaire", citou este poeta, autor não só do poema "O vinho dos trapeiros", mas também de uma descrição do trapeiro que aproxima esta figura urbana moderna do trabalho do próprio poeta. Podemos, mutatis mutandis, aproximar também esta figura de trapeiro, à do autor implícito de Grande Sertão: Veredas:

Aqui temos um homem - ele tem de recolher na capital o lixo do dia que passou. Tudo o que a cidade grande jogou fora, tudo o que ela perdeu, tudo o que desprezou, tudo o que destruiu, é reunido e regis- 
trado por ele. Compila os anais da devassidão, o cafarnaum da escória; separa as coisas, faz uma seleção inteligente; procede como um avarento com seu tesouro e se detém no entulho que, entre as maxilas da deusa indústria, vai adotar a forma de objetos úteis ou agradáveis.

O interessante de se ver nesta obra uma tal coleção do resto da civilização, ou seja, do que restava da vida não-urbana na cultura brasileira, é que novamente vislumbramos aqui algo que pode ser aproximado do registro da poética do testemunho. Nesta observamos a possibilidade de se dar voz àqueles que não tinham lugar no universo simbólico e econômico. A perspectiva do testemunho é a da história dos vencidos. Na obra em questão tendemos a também nos solidarizar com este mundo em extinção, que como que acena, na pena de um autor que, ironicamente, mistura um regionalismo reinventado com Dostoievski, Joyce, e outros grandes autores da história da literatura e da filosofia. ${ }^{4}$

Uma das características mais marcantes desta sofisticada construção narrativa é justamente esta mistura de referências. Por exemplo, na medida em que o texto se apresenta como uma longa narrativa das aventuras do protagonista Riobaldo, este se torna uma espécie de aedo, com o perdão do jogo de palavras evidente, ele se revela um Rio-bardo. A própria voz narrativa se torna, assim a protagonista. Como no canto IX da Odisseia, quando Ulisses, em meio aos feáces, não só se emociona ao ouvir de um aedo as suas próprias aventuras, como ele mesmo narra outras passagens de sua história, transmutando-se os papéis de Homero com o de Ulisses. Em Grande Sertão: Veredas, não é só a lei da força, a astúcia, a lei dos bravos que impera, também temos profetisas, amizades inabaláveis e grandes atos de hospitalidade e uma estrutura episódica, como em Homero. E ainda: o tempo e a morte são pensados em torno do conceito de glória, kléos, termo-chave na poética da epopeia homérica. O livro de Rosa faz inúmeras referências aos sucessos cantados das sagas dos bravos jagunços; como também ocorre na epopeia, sua musa é Mnemósine. Mesmo o outro polo dialético

${ }^{4}$ Mas vale notar também, que tanto no gesto do autor implícito de Grande Sertão como no do gestor de testemunhos, existe uma violência em jogo: uma hierarquia produzida por uma diferença de saberes e de domínio de códigos e também pelo lugar que o gestor e o colecionador de logoi ocupam na sociedade. Trata-se de uma "tradução" de um código oral para o da escrita e nesta transposição tudo é transformado. É importante não deixar escapar esta ambiguidade que marca a figura deste criativo e estranho colecionador de histórias: ele é compassivo e violento. 
da epopeia, a vingança, motor das ações, está no coração do livro de Rosa. É dispensável dizer que toda esta estrutura narrativa épica não só é a base das narrativas literárias e históricas posteriores, mas também vai alimentar o próprio gesto testemunhal.

Para finalizar gostaria de tomar duas passagens, como que episódicas, que permitem enfatizar esta relação do romance rosiano com a confissão e o testemunho. Refiro-me à passagem narrada por Jóe, o "caso de Maria Mutema e do Padre Ponte" e ao julgamento de Zé Bebelo. Estas duas passagens - das mais conhecidas do romance - têm uma a confissão auricular, a outra o testemunho no seu centro.

\section{Maria Mutema: confissão como castração e phármakon}

Jõe conta que Maria Mutema, "mulher em preceito sertanejo", de repente havia perdido seu marido. Em seguida, ela se tornou fervorosa religiosa e passou a frequentar assiduamente a igreja. Estas visitas tinham por objetivo mais as suas confissōes com o Padre Ponte (pai de três crianças), que eram infindáveis e sempre pareciam escandalizá-lo muito. Lemos no texto uma bela descrição do ato de linguagem confessional: "Mas o que logo se soube, e disso se falou, era em duas partes: que a Maria Mutema tivesse tantos pecados para de três em três dias necessitar de penitência de coração e boca; e que o Padre Ponte visível tirasse desgosto de prestar a ela pai-ouvido naquele sacramento, que entre só dois se passa e tem de ser por ferro de tanto segredo resguardado." Finalmente o padre adoeceu e morreu. Aparentemente, mas de modo incompreensível, ele morrera de excesso de confissão. Em seguida chegaram dois padres estrangeiros missionários no arraial e, uma feita, em uma missa, Mutema reaparece na igreja: imediatamente o padre, que mal concluía a sua reza, ordenou que ela se retirasse da igreja, pois guardava "maus segredos" e deveria depois fazer sua confissão diante do cemitério. ${ }^{5}$ Mutema começou a confessar-se ali mesmo, diante de todos, a "verdade" rompeu o dique de seu silêncio: "E rompeu fala, por entre prantos, ali mesmo, a fim de perdão de todos também, se confessava." "Assim ela libertou de si seu terrível segredo: ela matara seu marido derramando chumbo em seu

\footnotetext{
${ }^{5}$ Este padre que de imediato reconhece quem é Mutema e já sabe de seus pecados é sem dúvida um duplo do padre de O Processo - uma das obras mais brilhantes sobre as aporias do direito e de suas instituiçóes, como a própria confissão -, que chama Josef K. pelo nome, quando este está só na igreja, e mostra saber toda sua história.
} 
ouvido enquanto ele dormia e depois teria mentido ao Padre Ponte em suas confissóes, dizendo que havia matado o marido por causa dele. Com isto teria levado o padre ao desgosto e à morte. Mutema presa, clamou por "perdão e castigo". E de fato, após passar por "culpa e júri", na cadeia de Arassuaí o povo afluiu para lhe perdoar. Ao fim concluíram que seu arrependimento humilde e sofrimento a estavam convertendo em santa. - Nesta pequena história dentro da história, como no teatro dentro do teatro em Hamlet, assistimos não só a esta mise en abyme da narrativa mas também à cena de um assassinato de um marido, por parte de sua esposa e utilizando o mesmo e peculiar modo, chumbo derretido derramado no ouvido. Mas se não temos na história de Mutema a utilização deste assassinato como meio de ascender ao poder, por outro lado, nas duas histórias vemos uma espécie de "estado de exceção" revelado por estes atos ignominiosos: em Hamlet o poder real é assaltado por este golpe, mostrando que a origem do poder soberano é a violência; em Grande Sertão o ato de Mutema é apenas mais uma exceção em um universo onde padres têm filhos. Sua ação é apresentada como uma espécie de prazer perverso em matar e ver morrer. Este gozo sintomaticamente passou nos dois assassinatos pelo canal auditivo. $\mathrm{O}$ primeiro homem foi assassinado pelo chumbo no ouvido e segundo pelo ferro e veneno de suas palavras. A confissão no fim da história - após gerar a morte do padre, mais confissão, sua condenação, o arrependimento e o perdão - acabou de fato purificando Mutema que se tornou uma espécie de santa.

A relação entre nosso canal auricular e os atos de fala confessionais e testemunhais é da maior importância. Como vimos, sem alguém para escutar, pronto a receber em seus ouvidos as palavras de dor ou de arrependimento, estes atos não podem se dar. Neste sentido, estes atos podem ser denominados como "otobiográficos", expressão utilizada por Derrida para qualificar de modo geral as autobiografias. Também os atos "otobiográficos" são onipresentes na vasta obra de Santo Agostinho, autor de Confissōes. E isso decerto responde a uma intertextualidade com os textos bíblicos: lembremos da passagem bíblica de Deus perfurando a orelha de seus seguidores com uma sovela; ${ }^{*}$ da descrição do sacrifício do novilho e do preceito que comanda que seu sangue deve ser posto na ponta da orelha direita de Arão e seus filhos;" das palavras de Josué: "Ajuntai perante mim todos os anciãos das vossas tribos, e vossos oficiais, e aos vossos ouvidos falarei estas palavras, e contra eles 
por testemunhas tomarei os céus e a terra"; "Inclinai os ouvido, ó céus, e falarei”; "Ouvindo-me algum ouvido, me tinha por bemaventurado; vendo-me algum olho, dava testemunho de mim"; "porque o ouvido prova as palavras, como o paladar prova a comida"; "Dá ouvidos às minhas palavras, ó Senhor; atende à minha meditação"; "Têm veneno semelhante ao veneno da serpente; são como a víbora surda que tem tapado os seus ouvidos”* etc. Estabelece-se nestas passagens um vínculo entre a audição e a entrega às palavras "que iluminam”, entre a fé e o canal auditivo que, por sua vez, é conjugado ao testemunho visual. O alimento (espiritual) vem da boca de Deus (que deve ser ruminado, diz Santo Agostinho) assim como - na aliança que une o fiel a ele - a boca daquele que confessa dirige-se aos ouvidos de Deus. A escuta transformase em manducação. Na história de Maria Mutema a escuta transforma-se não tanto em manducação e ruminação, mas antes em indigestão. As palavras convertem-se em chumbo que penetram os ouvidos do Padre Ponte. Mas as metamorfoses não param aí. A palavra da confissão é sempre palavra de "conversão": de circonfissão, dirá Derrida. Mutema de fato se converte e re-converte: primeiro em "onça monstra, tinha matado o marido", "cobra, bicho imundo", ' depois em santa. A ideia de aproximar confissão e circuncisão - formando circonfissão - pode ser derivada do fato de que no cristianismo tanto o testemunho, como a confissão têm a ver com esta transformação do eu, com o evento de uma metamorfose que também sela um pacto, um anel que une o indivíduo com Deus. Citemos as palavras de Santo Agostinho: "Se é verdade que na carne do homem circuncidado eu não posso encontrar o local onde repetir a circuncisão, pois o membro é único, ainda menos podemos encontrar o local em um coração onde se repetir o batismo de Cristo. É por causa disto que para vocês que querem duplicar o batismo, é absolutamente necessário que vocês procurem corações duplos." Mutema de certo modo mostrou uma iterabilidade deste gesto que para Santo Agostinho seria irrepetível. Ela busca uma suplementação fálica para construir sua aliança de carne com Deus. Ela encontrou de fato dois falos que ela como que sacrificou, castrou, para com eles conquistar suas alianças de carne e assinar o pacto de fé e sua confissão. Sua história mostra como a confissão é um phármakon amargo-doce que pode tanto matar como salvar.
* (De. 31,28)

* (Último cântico de Moisés; De. 32,1$)$

* (Jó 29, 11)

* (Jó 34,3)

* (Sal. 5,1)

* (Sal. 58,4)

* (ROSA, idem: 172.)

* (Epist. 23, 4, apud CHRÉTIEN, 2002: 238.) 
* (MARGALIT, A. The ethics of Memory, Londres, Cambridge: Harvard University Press, 2002: 176.)
Testemunho falocêntrico: o "falo" como fala e órgão sexual

Esta relação entre falo como órgão genital masculino e o ato de fala apenas explicita o aspecto falocêntrico do testemunho e da confissão. O testemunho, sobretudo em seu sentido de testemunho de um terceiro, do testemunho jurídico, é falocêntrico. Nas sociedades tradicionais as mulheres são excluídas das cortes enquanto testemunhas. Josephus afirma que nos tempos bíblicos isto ocorria, o mesmo valendo para a "mulher romana". Daí Riobaldo se voltar em seu discurso testemunhal a um senhor e não a uma senhora. A lógica do testemunho é a do convencimento via apresentação espetacular, super ocular, de provas. Prova-se um crime como se prova a masculinidade. A cena do testemunho falocêntrico tem sua representação mais acabada na Eumênides de Ésquilo, que apresenta o tribunal com o julgamento de Orestes, que é absolvido de seu ato de matricídio. Palas Atena vota no partido dos homens, de Zeus, Apolo e Orestes, contra a apelação das Fúrias, que, defendendo Clitemnestra, voltam-se para a mãe delas, a Noite. Em Grande Sertão: Veredas encontramos também uma Palas Atena que, como na tragédia de Ésquilo, é apresentada como alguém que não teve mãe: Diadorim. Este personagem, híbrido como a deusa grega, também vota no partido dos homens. Vale notar que, diferentemente de Clitemnesta, que foi morta pelo seu ato conjugicida, Mutema soube se precaver com a astúcia da "dupla" confissão fálica.

Neste sentido é interessante destacar como no julgamento de Zé Bebelo existe uma espécie de espelhamento do próprio julgamento de Orestes. Ambos réus são perdoados, absolvidos. Os dois tribunais representam de certo modo uma forma de transição entre a justiça tradicional, a lei do talião, feita com base em provações de culpa e puro exercício da força, e a lei do tribunal, com seus jurados e a tentativa de construção de uma justiça neutra: "cega". Os testemunhos neste tribunal oscilam entre estes dois modelos de justiça. Hermógenes, o primeiro a falar sua acusação, não apresenta provas, apenas condena o réu à morte. Sô Candelário - após sugerir um duelo com o réu, o que significaria uma contradição com a ideia de julgamento - defende Zé Bebelo, apelando para a lei da guerra: não seria crime guerrear. $\mathrm{O}$ jus in bello justifica - com um estado de exceção da guerra - os atos de violência. Ricardão, o terceiro a testemunhar, tem como argumento a necessidade da vingança, quando a justiça justamente pretende se colocar acima deste patamar subjetivo. Riobaldo pondera, após estas três falas, que oscilava entre 
um ponto de vista e outro. Mas conclui que todo julgamento é defeituoso "porque o que a gente julga é o passado. [...] Quem julga já morreu." Neste ponto a justiça é posta em questão devido a este fato cronológico insuperável: o julgado não é o criminoso, pois o crime está sempre no passado. $\mathrm{O}$ julgamento, em sua inevitável "posteridade" estará sempre em descompasso com o que é julgado. Os demais jagunços falam a favor de Zé Bebelo. Tião Passos recorda que na lei do sertanejo ou se mata no calor da hora, ou não. Como o próprio Ricardão havia falado: "Lei do jagunço é o momento". Novamente vemos posta a incompatibilidade cronológica do julgamento com o ponto de vista jagunço. $\mathrm{O}$ próprio Riobaldo ao falar seu testemunho não apenas apela para seu profundo conhecimento do réu em uma chave bem visual - "Vi. Testemunhei"* - como também apela para a glória (kléos) daqueles homens ali reunidos após a batalha. Eles não a teriam se matassem alguém deste modo não-jagunço, covarde, após a pausa suspensiva de um julgamento. Sô Candelário concorda com este argumento em favor da "fama de glória”. Este julgamento circula constantemente entre a lei do talião e a do tribunal, apagando as fronteiras entre o "estado natural" e a civilização da cidade e da justiça positiva. $\mathrm{O}$ pressuposto pacto, que na teoria política clássica estaria na origem da vida civilizada, é revelado como sendo, antes, um pacto com a força bruta. No final do julgamento Joca Ramiro revela toda a arbitrariedade deste ritual ao decretar o seguinte, em sua condenação de Zé Bebelo ao desterro temporário: "O julgamento é meu, sentença que dou vale em todo este norte." Como também se passa na Eumênides, a anomia que deveria ser barrada e contida pelo dispositivo do tribunal é, na verdade, aprofundada por ele: as Fúrias são incorporadas como parte do sistema jurídico. Este julgamento é também uma espécie de teatro dentro do teatro, figura da figura do romance. Ele põe em cena o testemunho como dispositivo de julgamento, de construção do indivíduo e, sobretudo, de poder. Nesta cena masculina, de bravos homens esgrimando com palavras não vemos a saída do universo jagunço, mas antes a desconstrução da própria justiça, que é apresentada como política masculina da força e das amizades. Joca Ramiro em seu veredicto é tão arbitrário quanto Palas Atena.

\section{Testemunho e confissão como ficções}

Concluindo, gostaria apenas de lembrar que não existe a possibilidade de se estabelecer uma fronteira entre a ficção e, por outro 
* (DERRIDA, J. "Circonfession", in: BENNINGTON,G. Jacques Derrida. Paris: Seuil, 1991: 103.)

* (Ibidem: 120.)

* (DERRIDA, J. Demeure. Maurice Blanchot, Paris: Galilée, 1998: 28.) lado, a confissão e o testemunho. Do mesmo modo, testemunho e confissão também são assombrados pela possibilidade de mentira. Como vimos, Riobaldo mesmo já desconfiava de que seu interlocutor achava que o que narrava era falso. Derrida foi um dos pensadores que melhor formulou estas ideias: "uma confissão não tem nada a ver com a verdade", " "uma circonfissão é sempre simulada", ele sentenciou. E ainda constatou: "[O] testemunho tem sempre parte com a possibilidade ao menos da ficção, do perjúrio e da mentira. Eliminada essa possibilidade, nenhum testemunho será possível e, de todo modo, não terá mais o sentido do testemunho."* Caberia pensar se a encenação testemunhal e confessional de Tatarana também não estaria sombreada pela ficção (da ficção). Ou seja, podemos nos perguntar se a solução de seu drama de consciência (revelar que Diadorim era uma mulher), não seria uma racionalização a posteriori. O desnudamento da verdade neste livro é o desnudamento do corpus delicti: Diadorim é mulher, a prova é a falta, a ausência do falo. O testemunho dá a ver o "nada", o vazio. Pensando-se esta ficção como um jogo confessional e testemunhal, podemos imaginar também que Diadorim na verdade, é claro, na verdade da ficção, era um homem. O veritatem facere é também uma ficta confessio. Ele e Riobaldo se amaram como dois bravos, como Aquiles e Pátroclo, só que, por assim dizer, fora do lugar: no tempo-espaço do sertão e não na Troia mítica. Daí a necessidade desta racionalização no ato confessional. A sobreposição de Troia com o sertão, ou o cruzamento das veredas de Ulisses com as de Riobaldo, engendraram um romance único no qual lemos uma trans-helenização do jagunço, que em seguida é quem sertaneja a Hélade. Este é apenas mais um dos aspectos que se pode desdobrar deste projeto de releitura de Grande Sertão como um ato confessional e de testemunho. Sabemos que para Riobaldo vale a regra: "Eu me lembro das coisas, antes delas acontecerem..." O que conta é a lembrança e sua performance e não algo que ela re-presentaria. ${ }^{6}$ Mas a

\footnotetext{
${ }^{6}$ Portanto, podemos apenas especular sobre estes não-ditos e desditos de Riobaldo testemunha e confessor. Evidentemente proponho um novo jogo de leitura, que leva em conta este elemento de construção do relato testemunhal e confessional. Não se trata de modo algum de dizer que Diadorim era "na verdade" um homem, pois de qualquer maneira toda verdade aqui é fictícia. Mas dentro desta ficção é possível se colocar esta hipótese de leitura acerca do falso testemunho de Riobaldo. Pode-se inclusive pensar também que ele "de fato" possui esta memória do corpo revelado de Diadorim como um corpo feminino, afálico: esta memória pode ser uma alucinação, um delírio ou uma construção posterior, como uma memória encobridora da "verdade" do corpo de seu amado. Estas hipóteses
} 
cena testemunhal do Grande Sertão: Veredas fecha-se de modo enfaticamente falocêntrico, destacando novamente o compromisso entre a apresentação do testemunho e o espetáculo da visualização do grande falo. Trata-se de um testemunho hiperbólico: é um sobre - ou supertestemunho. O grande de Grande sertão é redito no parágrafo final do livro, como se fosse um mastro a demarcar a última cena do testemunho: "O Rio de São Francisco - que de tão grande se comparece - parece é um pau grosso, em pé, enorme..."* O Velho Chico - duplo do velho Riobaldo - aqui nesta passagem é tanto uma figura da torrente caudalosa da narrativa, como do falo. E o autor continua: "Amável o senhor me ouviu [...] O senhor é um homem soberano, circunspecto": nós fomos fecundados por esta fala e suas sementes. Nossos ouvidos senhoriais estão agora nos investindo de soberania sobre este testemunho. Este se dissemina então em infinitas leituras. As veredas, como o sertão na sua apenas aparente infertilidade ${ }^{7}$, não têm fim.

\section{Márcio Seligmann-Silva}

Márcio Seligmann-Silva é professor livre-docente de Teoria Literária na UNICAMP e pesquisador do CNPq. É autor de Ler o Livro do Mundo (Iluminuras, 1999), Adorno (PubliFolha, 2003) e O Local da Diferença (Editora 34, 2005); organizou os volumes Leituras de Walter Benjamin: (Annablume/FAPESP, 1999; 2a . edição 2007), História, Memória, Literatura: o Testemunho na Era das Catástrofes (UNICAMP, 2003) e Palavra e Imagem, Memória e Escritura (Argos, 2006) e coorganizou Catástrofe e Representação (Escuta, 2000).

\section{Resumo}

O trabalho apresenta uma leitura do romance de Guimarães Rosa de 1956 do ponto de vista de uma série de topoi desenvolvidos dentro da teoria da confissão e do testemunho: Riobaldo testemunha

podem ser sustentadas dentro desta poética que apresentei aqui, mas tudo fica em suspenso, pois trata-se de "verdades da ficção".

${ }^{7}$ Nesta passagem introduzo um jogo entre a ideia de sobre- ou supertestemunhar e o conceito de infertilidade. Benjamin em seu Rua de mão única escreveu que "Überzeugen ist unfruchtbar", ou seja: "convencer é infecundo", sendo que Überzeugen pode ser lido de modo analítico como uma palavra-valise significando supergerar, supercriar, superfecundar. Zeugen tem estes dois sentidos: testemunhar e fecundar. Cf. SELIGMANN-SILVA, M. "Testemunho e a Política da Memória: O Tempo depois das Catástrofes”. In: Projeto História, Revista do Programa de Estudos Pós-Graduados em História e do Departamento de História da PUCSP, no. 30, pp. 31-78, jun. 2005: 77.
* (ROSA, idem: 560.)

Palavras-chave: testemunho; confissão; falocentrismo; memória do trauma. 
passagens de sua vida diante de um ouvinte/dos leitores. A violência do sertão, derivada em parte do jogo entre a anomia e a lei da força, desdobra-se nas angústias derivadas do amor impossível por Diadorim. Como em muitos textos de forte "teor testemunhal", a fragmentação da memória e a sua espacialização guiam o fluxo da narrativa. Constrói-se ao longo do livro uma "topografia da memória”, que é lida como uma encenação de uma memória do trauma. Oscilando entre testemunho e confissão, o texto permite uma leitura do trabalho literário funcionando como a encenação de um teatro da memória da "catástrofe". O tema da relação intrínseca entre lei e violência, assim como o espetáculo do corpo em dor, também presentes no livro, são outras características de atos testemunhais. Apresenta-se também o elemento falocêntrico do testemunho e da confissão atuando no romance. Mostra-se como tudo fica muito mais interessante ao vermos estes topo $i$ atuando dentro de um texto sofisticado de ficção, que também os transforma.

Key words: testimony; confession; falocentrism; trauma memory.

Mots-clés: témoignage; confession; phallocentrisme; mémoire du trauma.

\section{Abstract}

The work presents a interpretation of João Guimarães Rosa novel from 1956 from the point of view of some topoi developed inside the theories of testimony and confession: Riobaldo witnesses some moments of his life before a listener/reader. The violence of "sertão", a consequence of the play between anomie and force, unfolds itself in the anguish derived from the impossible love to Diadorim. As in many other texts with strong "testimonial tenor", the memory fragmentation and its spacialization guide the narrative stream. The work built a "topography of memory" that is analysed as a simulation of a traumatic memory. Oscillating between testimony and confes-

\section{Résumé}

Ce travail présente une lecture du roman de João Guimarães Rosa publié en 1956 à partir d'une série de topoi développés dans la théorie de la confession et du témoignage: Riobaldo témoigne de certains passages de sa vie devant un auditeur / des lecteurs. La violence du "sertão", provenant en partie du jeu entre l'anomie et la loi de la force, se déplie dans les angoisses dérivées de l'amour impossible de Diadorim. Comme dans maints textes à fort "contenu testimonial", la fragmentation de la mémoire et sa spatialisation guident le flux narratif. Il se construit tout au long du livre une "topographie de la mémoire», qui est lue comme la mise en scène d'un théâtre de la mémoire de la "ca- 
sion, the text authorizes a reading of the literary work functioning as the mise en scène of a memory of a catastrophe. The question of the intrinsic relation between law and violence, as much as the spectacle of the body in pain, that we can also read in this novel, are other characteristics of testimonial acts. The essay presents too the falocentric element that is present both in confession and testimony as well as in this book. It is showed that the presentation of all those testimonial and confessional elements inside a sophisticated work of fiction send also a new light over those topoi. tastrophe". Le thème du rapport intrinsèque entre la loi et la violence, de même que le spectacle du corps souffrant, également présents dans le livre, constitue d'autres caractéristiques de l'acte testimonial. On y présente aussi l'élément phallocentrique du témoignage et de la confession en action dans le roman. On montre comment tout devient plus intéressant lorsque nous voyons ces topoi dans un texte sophistiqué de fiction qui les transforme à son tour. 